\title{
ANALYSIS OF WATER QUALITY TO INDUSTRIAL AND RESIDENTIAL DEVELOPMENT AREA IN BOGOR, WEST JAVA, INDONESIA
}

\section{(A CASE STUDY)}

\author{
Meike Elsye Beatrix, Titia Izzati*, Fauzan Abdu Razak, and Aris Pratama \\ Industrial Engineering Program, Engineering Faculty, Universitas Mercu Buana, 11650, Jakarta, Indonesia \\ E-mail: meike@mercubuana.ac.id, meike.beatrix@yahoo.com, *titia.izzati@mercubuana.ac.id, *tizzati@gmail.com, \\ fauzanrazak12@gmail.com, pratamaaris938@gmail.com
}

\begin{abstract}
This study aims to determine the water quality of industrial sector development in Bogor Regency. Water quality was analyzed based on the measurement of water samples of acidity (pH), Total Disolved Solids (TDS), and water temperature (Temperature). Water samples are taken periodically in residential and industrial areas for two months. The average result of measurement of residential area water samples; pH 8.38, TDS 95.25 ppm, and temperature $30.8^{\circ} \mathrm{C}$. Average yield of industrial area measurement; $\mathrm{pH} 8.81$, TDS $171.88 \mathrm{ppm}$, and temperature $31.81^{\circ} \mathrm{C}$. From the data, it can be concluded that water quality in residential areas is still feasible to be consumed, while water in industrial areas is not feasible for consumption. This determination refers to the Regulation of the Minister of Health No. 416/MEN.KES/PER/IX/1990 on the provision and monitoring of water quality.
\end{abstract}

Keyword: total dissolved solids, temperature, industry, Bogor, acidity.

\section{INTRODUCTION}

Bogor is one of regencies in West Java Province with an area of $\pm 298,838.31 \mathrm{Ha}$. Geographically located between $6^{\circ} 18 \quad 6^{\circ} 47^{\prime} 10$ LS and $106^{\circ} 23^{\prime} 45-107^{\circ} 13^{\prime} 30$ BT. Climatically, the Bogor Regency area includes a very wet tropical climate in the South and a wet tropical climate in the North, with an annual bulk rate of 2,500 - $5.00 \mathrm{~mm} /$ year, except in the northern and eastern regions of less than $2,500 \mathrm{~mm} /$ year.

The average temperature in the area of Bogor Regency is $20^{\circ} \mathrm{C}-30^{\circ} \mathrm{C}$, with an average annual temperature of $25^{\circ}$. The air humidity is $70 \%$ and the wind speed is quite low, with an average of $1.2 \mathrm{~m} / \mathrm{sec}$ with evaporation in the open area averaging $146.2 \mathrm{~mm} /$ month.

Bogor Regency is included in a strategic area in the development of industrial and residential areas as well[1, 2]. This is because the location of Bogor Regency is close to the Capital of Jakarta and crossed by the Jakarta-BogorCiawi (Jagorawi) toll road. Industrial areas in Bogor Regency include: Sentul Industrial Estate, Cibinong Center Industrial Estate (CCIE), Bogorindo and Menara Permai. The rapid development of industries and residential areas in Bogor impact on changes in water quality. In such circumstances, water is one of the commodities that need attention, because it involves human needs is very vital. If the water is polluted, and has a below normal $\mathrm{pH}$ value due to contamination of waste generated by industry, household and transport, water becomes unfit for consumption by the local population. Because the industrial environment is growing so fast, research should be done regularly to check the industry's impact on water quality[3-6].

Bogor areas is close to Jakarta, which has many pollution studies[7-15], Bogor itself has been studied for the open space and pollution [9, 16, 17]. The open space research was supported by the study of social welfare and young generation under the Ministry of Young and Sport Of Republic Indonesia[18-20].

Furthermore, the aims of this research were to analyze the quality of tap water surrounding industrial and residential development areas in Bogor.

\section{RESEARCH METHODS}

The common procedures of water quality was employed in this research[21, 22].

1. Place and time

Water sampling was conducted in residential and industrial areas in Jonggol Sub-district, Bogor. Water sampling is conducted regularly on September 3, 2017 to November 4, 2017.

2. Tools and materials

a. Total Dissolved Solids (TDS)

Water Tester is used to know solid objects dissolved in water molecules $\left(\mathrm{H}_{2} \mathrm{O}\right)$.

b. $\mathrm{pH}$ Meter, employeed to measure the $\mathrm{pH}$ of water.

c. Thermometer, performed to measure water temperature $\left({ }^{\circ} \mathrm{C}\right)$

\section{RESULTS and DISCUSSION}

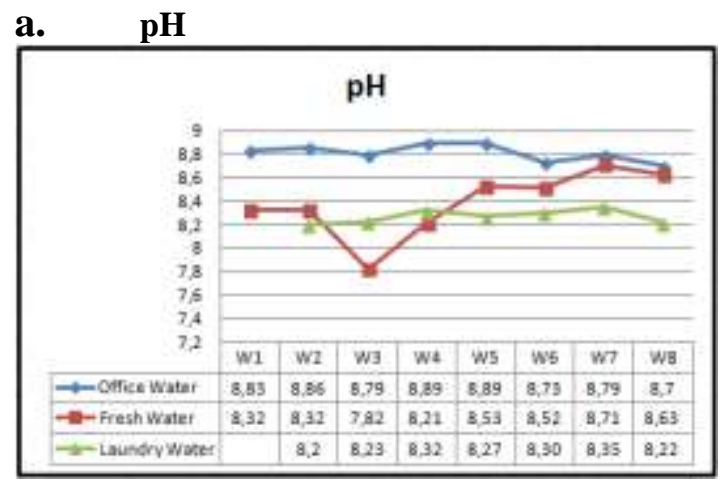

Figure 1. Graph of pH

Based on the data in Figure1, pH of the water sample, the residential area has a minimum water $\mathrm{pH}$ of 8.2 in the first week and a maximum water $\mathrm{pH}$ of 8.35 at week six. While the industrial area has a minimum water $\mathrm{pH}$ of 8.7 at the eighth week and a maximum water $\mathrm{pH}$ of 8.89 at week four and week five. From the above data, the average $\mathrm{pH}$ value of water is 8.27 for residential area and 8.81 for industrial area.

Referring to Regulation of the Minister of Health No. 416 / MEN.KES / PER / IX / 1990 on Water Quality and Condition Monitoring, states that the $\mathrm{pH}$ of water standard for health consumption is in the range of 6.5 to 8.5. Based 
on the regulation, it can be determined that water in residential areas is still feasible for consumption, while water in industrial areas is not feasible for consumption because it has exceeded the specified limits.

\section{b. TDS}

TDS Graph of water sample is shown in Figure 2. The minimum TDS value of settlement area is $98 \mathrm{ppm}$ and maximum is $244 \mathrm{ppm}$. For industrial areas the minimum TDS value is $115 \mathrm{ppm}$ and the maximum value is 140 ppm. Then the average value of TDS for residential areas is $185.29 \mathrm{ppm}$ and industrial area is $131.88 \mathrm{ppm}$.

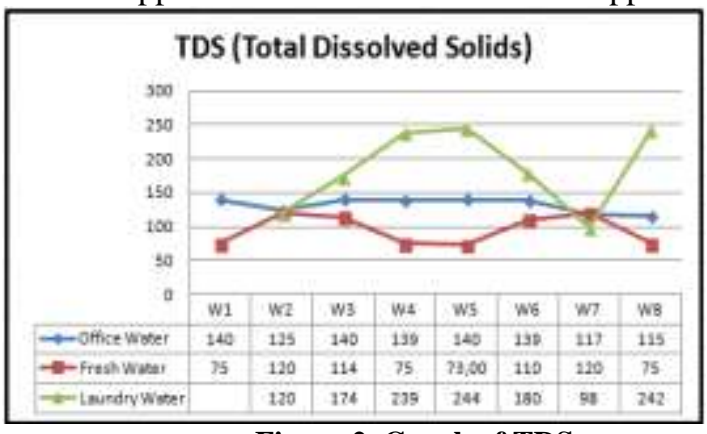

Figure 2. Graph of TDS

Based on the division of TDS values in general[23, 24]: Level of TDS (part per million) Assessment Less than 300 Very good

$300-600 \quad$ Good

$600-900 \quad$ Can be drunk

$900-1,200 \quad$ Not good

$900-1,200 \quad$ Unacceptable

In Indonesia the maximum level of TDS for drinking water is $500 \mathrm{ppm}$ for drinking water

The limit of TDS for Clean water is $1,000 \mathrm{ppm}$.

Based on the above requirements, the water in residential areas and industrial areas are included in the excellent category to be consumed because the value is less than 300 ppm or less than $500 \mathrm{ppm}$.

\section{c. Temperature}

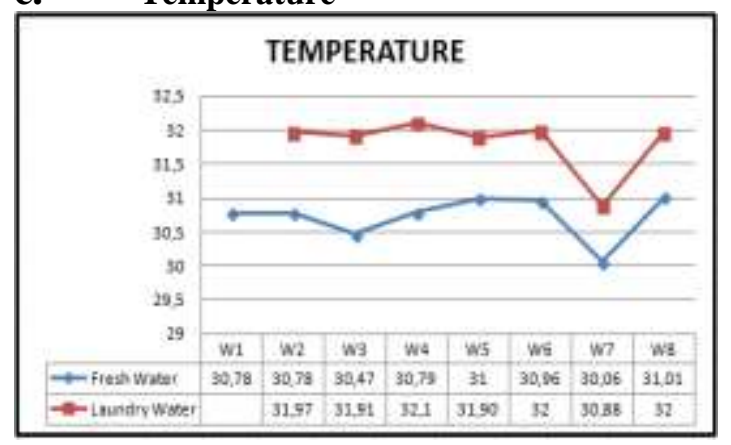

Figure 3. Graph of Temperature

Based on the result shown in igure 3, the minimum temperature value is $30,43{ }^{\circ} \mathrm{C}$ and the maximum value is $31,45^{\circ} \mathrm{C}$. While the temperature in the industrial area the minimum value of $31.79^{\circ} \mathrm{C}$ and the maximum value of $32.11^{\circ} \mathrm{C}$. The average value of the temperature of the $31^{\circ} \mathrm{C}$ residential area and the industrial area of $32^{\circ} \mathrm{C}$.

Water temperature by type can be divided into 3[25], namely:

- Cold water (cold water) water temperature $28-32^{\circ} \mathrm{C}$

- Warm water (warm water) water temperature 40 $50^{\circ} \mathrm{C}$

- Hot water (hot water) water temperature $60-80^{\circ} \mathrm{C}$
Therefore, from the above requirements, the water settlement areas and industrial areas are classified in cold water. However, if it refers to the average temperature of the Bogor area, there is an increase between $1^{\circ} \mathrm{C}$ to $2^{\circ} \mathrm{C}$.

In addition, Figure 3 shows that the highest Temperature is water laundry, the cause is the excessive use of excessive water detergent and also can be caused by manyhe industries, especially laudry, in Bogor area.

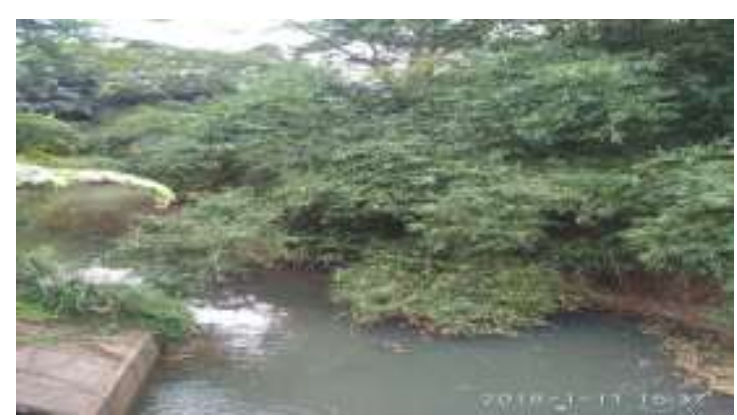

Figure 4. River in Bogor

From the data, it can be concluded that water quality in residential areas is still feasible to be consumed, while water in industrial areas is not feasible for consumption. This determination refers to the Regulation of the Minister of Health No. 416/MEN.KES/PER/IX/1990 on the provision and monitoring of water quality[26, 27].

\section{CONCLUSION}

1. Based on the average value of water $\mathrm{pH}$, the residential area with a water $\mathrm{pH}$ of 8.27 is still the requirement of consumption water consumption, while the industrial area with a water $\mathrm{pH}$ of 8.81 has been polluted because it exceeds the $\mathrm{pH}$ value limit that has been determined by the Ministry of Health

2. TDS value and water temperature is said to be normal, because it does not exceed the limits and there are significant changes.

3. Need for further waste management in the industrial area so that the waste produced does not pollute the environment, especially water or river.

\section{ACKNOWLEDGEMENTS}

This research was supported by The Students of Chemistry and Enviromental Study Classes Reg 1 \& 2: 16066/Gasal/2017-2018 and The Students of Environmetal Engineering Study Class Reg 2: 82011/Gasal/2017-2018, Universitas Mercu Buana Kampus D, Indonesia.

\section{REFERENCE}

1. Indonesia, P.R., Editor 2007, Undang-undang Republik Indonesia Nomor 26 Tahun 2007 tentang Penataan Ruang, Jakarta, from Jakarta

2. Indonesia, U.-U.R., Editor 1992, Perumahan dan Permukiman, Kementrian Negara Republik Indonesia: Jakarta, from Kementrian Negara Republik Indonesia

3. Stauffer, J., 2013, The water crisis: Constructing solutions to freshwater pollution. 2013: Routledge.

4. Stern, A.C., 2014, Fundamentals of air pollution. 2014: Elsevier.

5. Caviglia-Harris, J.L. and R.T. Melstrom, 2015. Airing Your Dirty Laundry: A Quick Marketable 
Pollution Permits Game for the Classroom. The Journal of Economic Education, 46(4): p. 412-419.

6. Hocking, M.B., 2016, Handbook of chemical technology and pollution control. 2016: Elsevier.

7. Izzati, T., 2016. An Initial Study Of The Air Pollution Through Rainwater In An Industrial Area Of Bekasi. World Chemical Engineering Journal, 1(2).

8. Izzati, T., 2016. An Initial Study Of The Air Pollution Through Rainwater In An Industrial Area Of Cikarang, West Java, Indonesia (A Case Study). Science International, 28(4).

9. Izzati, T., 2017. Water Quality Analysis Of Residential And Industrial Areas In Bogor, West Java, Indonesia. Science International, 29(2): p. 37370.

10. Izzati, T., et al., 2016. An Initial Study Of Laundry Industrial Effects To The Water Pollution In East Jakarta. IOSR Journal of Environmental Science, Toxicology and Food Technology 10(9): p. 35-37.

11. Izzati, T., et al., 2016. An Initial Study Of Industrial Area's Effects For The Air Pollution Through Rainwater In East Jakarta. IOSR Journal of Mechanical and Civil Engineering, 13(4): p. 159162.

12. Izzati, T., et al., 2016. An Initial Study Of Laundry Industrial Effects To The Water Pollution In Bekasi. IOSR Journal of Business and Management, 18(8): p. 109-111.

13. Amalia, M., B.P. Resosudarmo, and J. Bennett, Editors. 2013, The Consequences of Urban Air Pollution for Child Health: What does Self Reporting Data in the Jakarta Metropolitan Area Reveal?,

14. Baum, G., et al., 2015. Local and regional impacts of pollution on coral reefs along the Thousand Islands north of the megacity Jakarta, Indonesia. PloS one, 10(9): p. e0138271.

15. Resosudarmo, B.P. and L. Napitupulu, 2004. Health and economic impact of air pollution in Jakarta. Economic Record, 80(s1): p. S65-S75.
16. Zain, A.F., et al., 2015. The detection of urban open space at Jakarta, Bogor, Depok, and TangerangIndonesia by using remote sensing technique for urban ecology analysis. Procedia Environmental Sciences, 24: p. 87-94.

17. Izzati, T., 2017. An Initial Study of the Water Pollution Analysis at Residential, Office Building and Industrial Area's in Bogor. World Chemical Engineering Journal, 1(4): p. 31-34.

18. Izzati, T., et al., 2015. Social Welfare Programs For Young Society In Indonesia. Science International, 27(5): p. 4715-4717.

19. Izzati, T., et al., 2015. An Education Profile Of Indonesian Youth In 2009-2013. Science International, 27(2): p. 1457-1460.

20. Izzati, T. and Y. Poerwanti, 2014. Enhancing The Productivity And Multifunctionality Of Open Space Using Simple Techniques In Green Buildings. Science International, 26(2): p. 689-690.

21. Izzati, T., 2017, Kimia dan Praktikumku. Buku Panduan Praktikum Kimia Sederhana Bagi Mahasiswa Teknik Mesin. 2017, Jakarta: Pustaka Mandiri.

22. Izzati, T., 2017, Kimia dan Praktikumku. Buku Panduan Praktikum Kimia Sederhana Bagi Mahasiswa Teknik Industri. 2017, Jakarta: Pustaka Mandiri.

23. Effendi, H., 2003, Telaah kualitas air, bagi pengelolaan sumber daya dan lingkungan perairan. 2003: Kanisius.

24. Fardiaz, S., 1992, Polusi air dan udara. 1992: Kanisius.

25. Warlina, L., 2004. Pencemaran air: sumber, dampak dan penanggulangannya. Makalah Pengantar ke falsafah Sains. Institut Pertanian Bogor. Bogor.

26. Siahaan, N.H.T., 2004, Hukum Lingkungan dan Ekologi Pembangunan. 2004: Erlangga.

27. Indonesia, M.K.R., Editor 2016, Peraturan Menteri Kesehatan No. 416 Tahun 1990 Tentang: Syaratsyarat Dan Pengawasan Kualitas Air. 